\title{
MOGYORÓDI EMESE
}

\section{OIDIPUS ÉS SÓKRATÉS: TUDÁS ÉS TUDATLANSÁG, TRAGIKUS ÉS FILOZÓFIAI KATARZIS}

\begin{abstract}
Az alábbi tanulmány összeveti a görögök két ikonikus alakja, Oidipus és Sókratés történetét, és megvizsgálja delphoi jóslatukra adott reakciójukat. Amellett érvel, hogy Oidipus vétke és hybrise nem másban áll, mint a „kettős tudatlanságban”, melytől a sókratési elenchos ('vizsgálat', 'cáfolat') megtisztítani szándékozik polgártársait. Sókratés - Oidipusszal ellentétben - elkerüli a tragédiát, mivel megszívleli a delphoi intést, az „ismerd meg tenmagad!” felszólítását. A sókratési filozófia egy olyan katartikus eljárás, melynek célja a tragikus katarzis elkerülése. A sophoklési tragédia és a sókratési-platóni filozófia ugyanarra az örök emberi tényezőre, a „kettős tudatlanság” hybrisére reflektál, s intésük is hasonló. Látszat és valóság, vélekedés és tudás között hányódva - miként az V. századi görögség - választásunk ma is ugyanaz: a tragikus és a filozófiai megtisztulás közötti.
\end{abstract}

Kulcsszavak: Oidipus, Sókratés, delphoi jóslat, hamartia, hybris, látszat, valóság, kettős tudatlanság, elenchos, katarzis, tragédia és filozófia

Jálics Ferenc SJ emlékére

Oidipus és Sókratés. Ki ne ismerné e neveket? Egyikük mitikus hős, a görög tragédiák alakjai közül talán a leghíresebb, akit Sophoklés Oidipus király és Oidipus Kolónosban című tragédiáiból ismerhetünk. A másik valóságos személy (Kr. e. 470/69-399), akinek története azonban legalább olyan mitikus dimenziókat öltött az évezredek során, mint Oidipusé. Hogy e nevek nemcsak fennmaradtak, de mintegy 2500 év távlatából is újra meg újra megszólítják az emberi sors, a condition humaine felől elmélkedőket arra utal, hogy olyasmit reprezentálnak, ami minden történelmi, társadalmi és kulturális változás közepette is állandóságot mutat az emberi természetben. Kulturális „ikonok”, ahogy ma mondani szokás.

Kétségtelenül nagy hatástörténetük párhuzamától eltekintve azonban ritkán hozzák összefüggésbe őket, és nem véletlenül. Oidipus a nagy bűnösök, nagy szenvedők, nagy tragikus hősök egyike, aki, miután kiderül számára, mit követett el, hogy - tudtán kívül bár, de - meggyilkolta saját apját, majd feleségül vette saját anyját és gyermekeket nemzett vele, megvakítja magát, és önként vállalt száműzetésbe vonul. Sókratés ellenben mondhatni a par excellence anti-tragikus hős, aki egész életében semmiféle bünt nem követett el, sőt, minden erejét az athéniak erkölcsi jobbításának és a delphoi isten (Apollón) szolgálatának szentelte, s noha élete vége felé mondvacsinált ürüggyel istentelenség és az ifjak megrontása vádjával perbe fogták, bünösnek találták és halálra ítélték, mindezt a lehető legnagyobb lelki nyugalommal viselte, hogy végül a szökés lehetősé- 
gét visszautasítva, tiszta lelkiismerettel, békességben távozzék e földi világból. ${ }^{1} \mathrm{~A}$ sorsok micsoda kontrasztja!

Persze mintha mégiscsak volna valami mélyebb hasonlóság e sorsok között. Talán nem egy ártatlan ember szenvedéséről, bukásáról, illetve haláláról van szó mindkét esetben? Hiszen Oidipus egyenesen elmenekül Korinthosból, amikor azt a jóslatot kapja Delphoiból, hogy meg fogja gyilkolni saját apját és feleségül veszi saját anyját. Ekkor azonban még nem tudja, hogy akit apjának vél (Polybos, a korinthosi király), nem az apja, akit anyjának (Meropé, a korinthosi királyné), nem az anyja. Épp emiatt tudunk együttérezni vele, hiszen úgy keveredik e történetbe, mint Pilátus a credóba! Másfelől talán nem tragikus Sókratés sorsa is, hiszen éppúgy ártatlanul, tehát igazságtalanul végezték ki, azt az embert, aki egész életében az erényekről beszélgetett az athéniekkel, és soha senkinek nem ártott (vö. Pl. Ap. 37a, Ep. VII. 324e)?

Valóban, bizonyos értelemben minden halál tragikus, hiszen veszteség valakinek, aki az elhunytat szerette, veszteség természetesen elsősorban magának az elhunytnak, az élet és szerettei elvesztése. Végső soron minden emberi sors tragikus, hiszen elkerülhetetlenül halállal végződik. A görögök nagyon is tudták ezt, amit többek közt az is alátámaszt, hogy a 'sorsra' használt kifejezésük (moira) gyakorta egyszerüen a 'halált' jelenti. ${ }^{2}$ A par excellence emberi 'osztályrész ${ }^{3}$ nem más, mint a halál - üzenik. Az istenek sújtotta Oidipus, aki tudtán kívül szörnyü bünökbe keveredett, illetve az életét Athén erkölcsi jobbításának szentelő, feddhetetlen és ártatlanul elítélt Sókratés innen tekintve egyaránt csupán az emberi élet végzetes kiszolgáltatottságát jelzi a szerencsének, a sorsnak, az istenek szeszélyének vagy egyenesen gonoszságuknak - kinek hogy tetszik. Ez a végső tanulság, ez a condition humaine: akár jók vagyunk, akár rosszak, akár bűnösök, akár ártatlanok, a végén mind tragikusan elbukunk. Okold bár magadat, másokat, a sorsot, az isteneket: „porból lettél, porrá léssz". Vagy ahogy Glaukos híres metaforája szól Homérosnál:

Mint levelek születése, olyan csak az embereké is.

Földresodorja a lombot a szél, de helyébe az erdő mást sarjaszt újból, mikor eljön a szép tavasz újra:

így van az emberi nemzet is, egy nő, más meg aláhull.

(Il. VI. 146-149)

1 Peréről két kortárs tudósítás maradt fenn, Platón: Sókratés védőbeszéde (Pl. Ap.) és Xenophón: Sókratés védőbeszéde birái elött (X. Ap.). A jelen tanulmányban Platónra támaszkodom. Xenophón művének történeti hitelességét megkérdőjelező érveimre vonatkozóan lásd Mogyoródi E.: A Sókratés-kérdés. Xenophón és a történeti Sókratés. AntTan 62 (2018) 1-29. Platón Kritón címủ dialógusa indokolja, hogy miért nem szökött el Sókratés a börtönből, s a Phaidón állít emléket halálának.

${ }^{2}$ Lásd például Hom. Il. VI. 488: (Hektór Andromachéhoz): „Jaj, te szegény, ne gyötörje ilyen nagy bánat a lelked! / Nincs oly férfi, ki sorson (aisa) túl Hádészra vet engem; / csakhogy a végzet (moira) elől, azt mondom, senkise futhat, / sem hitvány, se nemes, miután megszülte az anyja." Homérost a továbbiakban is Devecseri Gábor fordításában idézem.

${ }^{3}$ A moira főnévnek ez az alapjelentése: 'rész' (pl. földrész, országrész), 'juttatott rész,' járadék,' 'osztályrész: 
A művészet azonban nem az élet, így esztétikai szempontból nem minden szenvedés vagy halállal végződő történet tragikus. Ezt Aristotelés teszi világossá, aki rámutat, hogy sem a bűnösök jogos vagy megérdemelt szenvedése, bűnhődése, sem az ártatlanok meg nem érdemelt, igazságtalan szenvedése nem tragikus (Arist. Po. XIII. 1452b28-1453a12). Az ilyen történetek ugyanis nem képesek felkelteni a katarzisra jellemző két specifikus, tragikus érzelmet, a szánalmat vagy együttérzést (eleos) és a félelmet (phobos). Márpedig ezek nélkül nincs tragikus hős, tragikum, és nincs megtisztulás (katharsis) - az ábrázolt bukás vagy pusztulás csupán az élet hétköznapi eseménye, akárcsak egy földre sodort falevél hangtalan hullása. ${ }^{4} \mathrm{~S}$ ha nincs megtisztulás, akkor nincs tanulság sem, nincs olyasmi, amit magunkkal vihetnénk a teátrumból, hogy jobb vagy legalábbis mélyebb, megfontoltabb, bölcsebb, „megtisztultabb” emberként élhessünk tovább. Avagy a tanulság csupán Glaukos bölcsessége, és nincs különbség Oidipus és Sókratés között - úgyhogy carpe diem! Éljünk, ahogy tudunk, mert úgyis meghalunk!

Nos, nem sok értelme volna ma is foglalkoznunk a görögökkel, ha bizonyos történeteikkel ne arra intenének: ez elhamarkodott konklúzió. Van különbség Oidipus és Sókratés között, mégpedig lényegét tekintve az, hogy az utóbbi elkerüli a tragédiát, az előbbi pedig egyenesen beléfut. Amiből az következik, hogy nem egyforma minden emberi sors, nem egyaránt tragikus. Nem mindegy tehát, hogy az a falevél miként hullik alá, ezért van választásunk, és nem vagyunk kiszolgáltatva az istenek kénye-kedvének. Még akkor sem, ha a halál végül mindenkit egyaránt elér, mert ez a végzetszerű emberi osztályrész. Ugyanis Sókratés maga választja sorsát, Oidipusra viszont rászakad.

Ami Oidipust és Sókratést mélyebb szinten összeköti, az elsősorban a valóság és a látszat viszonya, illetve ezzel szoros összefüggésben a tudás vagy a bölcsesség birtoklásának, hiányának vagy illúziójának toposza, mégpedig cselekvéseinkkel, erkölcsi felelősségünkkel és sorsunkkal összefüggésben. Oidipus nevét az etimológusok az oideó ('dagad') igével kötik össze, hiszen a mítosz szerint amikor Laios király újszülött fiát kitétette, szolgájával összekötöztette a bokáját (S. OT 1032-1036). Ám a történet sophoklési változata a név más etimológiai asszociációit is játékba hozza, nevezetesen az oida ('tud, ismer') igét. ${ }^{5}$ Oidipus ugyanis megfejti a Thébát rettegésben tartó Sphinx talányát, így Théba megmentőjeként a nép ily módon megmutatkozó bölcsessége miatt királynak választja (s egyúttal elnyeri az özvegyen maradt Iokasté kezét is). ${ }^{6}$ Sókratés hasonlóképp

${ }^{4}$ A váratlan fordulat (peripeteia) és a felismerés (anagnórisis) Aristotelés meghatározásában a tragikum lényegi összetevői: ezek vezetnek a félelemhez és a szánalomhoz, a két katartikus érzelemhez (Po. XI. 1452a22-1452b13). A legjobb, ha a tragédiában a fordulat és a felismerés egybeesik, mint az Oidipus királyban (Arist. XI. Po. 1452a32-33). Erre vonatkozóan lásd J.-P. Vernant: Ambiguity and Reversal: On the Enigmatic Structure of Oedipus Rex. In: J.-P. Vernant - P. Vidal-Naquet: Myth and Tragedy in Ancient Greece. New York (1990) 116-117.

${ }^{5}$ Az oida igére vonatkozó allúzióra Oidipus nevében Vernant hívja fel a figyelmet. Lásd Vernant: i.m. (4. j.) 124 .

${ }^{6}$ Sophoklés számos helyen utal Oidipus okosságára vagy bölcsességére (pl. OT 31-45, 390-398, 507-511). 
valamiféle bölcs (sophos) hírében áll Athénban kérdezgető vizsgálódásai, illetve az ifjakkal folytatott beszélgetései okán (Pl. Ap. 18c, 20d, 23a, 34d-35a).

Ezzel azonban a párhuzam véget is ér, ugyanis lényegi eltérést mutatnak a tekintetben, ahogyan e státuszukhoz, illetve a bölcsességhez magához viszonyulnak. Mindketten kapnak ugyanis egy-egy zavarba ejtő jóslatot Delphoiból, és ez kulcsszerepet játszik történeteikben. Sorsuk és jellemük kontrasztja azon keresztül világítható meg, ahogyan a jóslathoz viszonyulnak. Ez ugyanis egyfajta önismereti vizsga mindkettejük számára, melyen Oidipus megbukik, Sókratés viszont átmegy. A kudarc, illetve a siker magyarázata szolgálhat bizonyos tanulságokkal számunkra ma is, hiszen a tömegmédia, a fake news, a „véleménybuborékok” korában látszat és valóság, tudás és nem-tudás viszonya talán élesebben vetődik fel, mint valaha - és adott helyzetben éppúgy az életünkre megy ki a játék, miként Oidipus vagy Sókratés esetében.

Hőseink sorsának kontrasztja tragédia és filozófia viszonyát is megvilágítja, pontosabban a tragikus sors elkerülésének lehetőségét a filozófia egy bizonyos, sókratési értelemben felfogott művelési módjának fényében. Mint látni fogjuk, a sókratési filozófia is katartikus, miként a tragédia, csakhogy míg az utóbbi esetében a katarzis a tragédia bekövetkeztét követően történik, az előbbi épp a tragikus katarzist szándékozik megelőzni. Platón ugyanis a filozófiát nem csupán diagnosztikus eszközként fogja fel - a társadalmi és politikai, illetve individuálpszichológiai zavarok és betegségek feltérképezése céljából ${ }^{7}$ - hanem sókratési gyakorlatát terapeutikus javallatként is ajánlja. $\mathrm{S}$ ahogy a diagnózis társadalmi szinten, ez a terápia egyéni szinten azt a célt szolgálja, hogy elkerülhessük a tragédiát.

\section{Oidipus és a rejtvényfejtés}

Lássuk először Oidipus tragédiájának fordulópontjait, hogy történetét a felvetett szempontokból értelmezhessük. ${ }^{8}$ A drámai előzmény, hogy Laios, a thébai király jóslatot kap Delphoiból: ha fia születik, meg fogja őt gyilkolni, és feleségül veszi saját anyját. A királyi párnak - mit tesz a sors - fia születik, így a jóslat beteltétől való félelmében Io-

7 Erre vonatkozóan lásd E. Vogelin: Order and History. Vol. 3. Plato and Aristotle. Baton Rouge - London (1957) 61-70, 85-88.

${ }^{8}$ Az archaikus kortól kezdve számos eposz megörökítette a thébai mondakört (töredékek maradtak fenn a Thébais és az Oidipodeia címűekből), az V. században több tragédiaíró is (ezek mind elvesztek). Sophoklést megelőzően Aischylos is írt belőle egy tetralógiát, azonban ebből csak a Heten Thébai ellen maradt fenn, így a mondakörből csupán Sophokléstől állnak rendelkezésünkre teljes művek (Oidipus király, Oidipus Kolónosban, Antigoné). A mondakör természetesen számos mítoszvariációt magában foglalt (például arról, hogyan került Oidipus a korinthosi udvarba, vagy egyáltalán ott élt-e, hogyan gyilkolta meg az apját, miként derült ki számára a kiléte, hogyan halt meg), ezek közül Sophoklésé csak egy - de koherens egészként fennmaradt - történetváltozat. Sophoklés - miként minden görög művész - kreatív módon válogat a különböző mitologémákból, hogy művészi céljait megvalósítsa. A különböző mitologémákról lásd T. Gantz: Early Greek Myth. A Guide to Literary and Artistic Sources. Baltimore - London (1993) 492-502. 
kasté, a királyné a csecsemő bokáját átszúratva egy szolgával kitéteti a Kithairón hegyre $\left(O T 711-719^{9}\right)$. A szolga azonban megszánja a csecsemő Oidipust, s odaadja egy korinthosi pásztornak, aki elviszi a gyermektelen királyi párhoz, akik örökbe fogadják (1016-1044, 1142-1182). Oidipus úgy nevelkedik fel, hogy mit sem sejt származásáról. Egy napon azonban tivornyázás közben valaki elszólja magát előtte, és „cserélt gyereknek” nevezi. Oidipus kérdőre vonja szüleit, akik azonban felháborodnak a híresztelésen, s nem árulják el az igazat. Ö gyanakodni kezd, és titkon Delphoiba megy, hogy ott derítse ki származását. A válasz helyett Apollóntól egy szörnyű jóslatot kap: saját apja gyilkosa és saját anyja férje lesz, akivel gyermekeket is nemz. Ezt hallván, a jóslat beteljesülésétől félve nem haza indul, hanem bujdokolni kezd (774-799).

Phókisba jutván egy hármas keresztútnál szekér jön vele szemben, s kocsisa ostorral parancsolja le a szűk útról. Oidipus nekiesik a kocsisnak, majd a szekér idős utasa fejbe vágja, mire Oidipus ököllel földre teríti és végez vele, valamint - egy kivételével, aki elmenekül - a többi három szolgával is (799-813). Mit sem sejt róla, hogy az előkelő férfiú a saját apja volt, Théba királya. ${ }^{10}$ Ezt követően érkezik Thébába, melyet a Sphinx (leányfejü, szárnyas oroszlán testű szörny) tart fogságában, aki a Phikion dombon ülve egy rejtvényt dalol, s valahányszor rossz megfejtést kap, az egy-egy thébai polgár életébe kerül. Az éles eszű Oidipus azonban megfejti a rejtvényt (36-37, 396-398, 506-515), ezért a város megmentőjeként királynak választják, s egyúttal elnyeri az özvegyen maradt királyné, Iokasté kezét is. ${ }^{11}$

Sophoklés darabja azon a ponton kezdődik, amikor - jó néhány évvel megérkezése után - pestis tör ki Thébaiban, és Oidipus elküldeti Kreónt (a sógorát) Delphoiba, hogy megtudakolja, mitévők legyenek. Kreón azzal a hírrel tér vissza, hogy a városnak meg kell tisztulnia a vérbűntől, mely Laios bosszulatlan gyilkosa miatt szennyezi. Oidipus szilárdan eltökéli, hogy felkutatja a gyilkost, de a gyilkosság körülményeire vonatkozó, még fellelhető információk elégtelensége miatt Teiresiasért, a vak jósért küldet, mivel ő belelát az istenek titkaiba (1-299). Teiresias elborzad, mikor meglátja Oidipust, és nem akar beszélni, vonakodik elárulni, hogy tudja, a keresett gyilkossal áll szemben. Erre Oidipus haragra gerjed, és először azzal vádolja, hogy cinkos a gyilkosságban, majd azzal, hogy Kreónnal összeszövetkezve a trónjára törnek. Teiresias végül nyíltan a fejére

\footnotetext{
9 A továbbiakban a drámára utalva csak sorszámokat adok meg. A szöveget Babits Mihály csodálatos fordításában idézem.

${ }^{10}$ Laios épp Delphoiba utazott (OT 114-115), valószínűleg, hogy megtudakolja, él-e még a gyermeke: H. W. Parke - D. E. W. Wormell: The Delphic Oracle. Vol. 1. The History. Oxford (1956) 300. Ekkor találkozott szembe vele, anélkül, hogy tudta volna, hogy a vándor saját fia.

11 A Sphinxre vonatkozóan Sophoklés igen szűkszavú, nem tér ki például zaklatásának módjára vagy okára, arra, hogy miként is veszejtette el a polgárokat, mi történt vele azután, hogy Oidipus megfejtette a rejtvényt, stb. A rejtvényre vonatkozóan azonban nagy valószínűséggel arra a mítoszváltozatra támaszkodik, melyet Asklépiadés (Kr. e. IV. századi mitográfus) őrzött meg: „Van egy kétlábú (dipus), háromlábú (tripos), négylábú (tetrapos) lény a földön, akinek egyetlen hangja van, / s ő egyedül változtatja alakját a földi, / égi s tengeri lények közül. Ám amikor három lábra támaszkodva / jár, tagjai akkor a leggyengébbek” (FGrH 12.7a, Jacoby). (Saját prózafordításom; a szöveg hexameterben maradt fenn.) A válasz: „az ember”, aki gyermekkorában a földön mászik, felnőttkorában két lábon jár, öregkorában botra támaszkodva.
} 
olvassa, hogy ő maga a gyilkos, akit kutat, s tudtán kívül fertőben él - mire Oidipus dühödten elkergeti (300-462).

A gyilkos utáni nyomozás Sophoklés ábrázolásában maga is egyfajta rejtvény, kirakós játék Oidipus számára, melynek darabjai lépésről lépésre állnak össze, míg végül kirajzolják a szörnyủ tükörképet. Az utolérhetetlen drámai feszültség forrása, hogy nem sejti, amit a nézők már kezdettől fogva pontosan tudnak: igaza van Teiresiasnak, ő maga a gyilkos, akit keres. ${ }^{12}$

Az első kirakósdarabkát Iokasté ejti el, amikor - meg akarván nyugtatni a háborgó Oidipust, ne adjon sokat jósok szavára, hiszen Laios is kapott egy jóslatot, hogy saját gyermeke kezétől fog elveszni, csakhogy rablók végeztek vele - mellesleg megemlíti, hogy a gyilkosság Phókis vidékén, egy hármas keresztúton történt (707-725). A helymeghatározás szöget üt Oidipus fejébe, s gyanakvása elmélyül, mikor Iokasté leírja Laiost és kíséretét. Az azonban nem egyezik a vele történtekkel, hogy Laios gyilkosaként több emberről, útonállókról adott hírt a kísérő, aki egykor elmenekült. A szolga még él, noha pásztorkodik valahol a hegyekben (ugyanis ezt a szolgálatot könyörögte ki a királynőtől, amint meglátta Oidipust a trónon) - úgyhogy elő kell keríteni, hogy tisztázzák, valóban több ember végzett-e Laiosszal. Különben nem lesz kizárható, hogy Oidipus volt a gyilkosa, ahogy Teiresias állította! Iokasté elküldet a szolgáért, de megnyugtatja Oidipust: bármit is mond majd a szolga, attól még nem lesz igaz a Laiosnak adott jóslat, hiszen a fia szegény csecsemőkorában meghalt, úgyhogy semmiképpen nem lehet a király gyilkosa $(750-768,836-862)$ !

Eközben hírnök érkezik Korinthosból azzal, hogy meghalt Polybos, úgyhogy - mint trónörökös - Oidipus király lesz ott is. A jó hír biztató: mivel Oidipus apja (akit tehát annak vél) halott, nem kell tovább aggódnia a neki szóló jóslat miatt! Azonban az anyja még él, úgyhogy nem teheti félre félelmeit: nem kizárható, hogy ha apját többé nem is ölheti meg, azért valamiképp mégiscsak elveszi az anyját. A hírnök azonban kész megnyugtatni: elárulja, ami Oidipust régóta aggasztja, és ami miatt egykor Delphoiba ment: nem köti őt vér szerinti kötelék sem Polyboshoz, sem Meropéhoz, ugyanis ő kapta egykor csecsemőként egy pásztortól a Kithairón hegyen, majd vitte el Korinthosba a királyi párhoz, akik örökbe fogadták. Lábait ő maga oldotta meg, mert gúzsba voltak kötözve, erről kapta Oidipus ('dagadtlábú') a nevét. Oidipus megdöbben ezen a sorson, és tovább faggatja a hírnököt, kitől kapta csecsemőként. A hírnök elárulja, hogy egy Laios népéhez tartozó pásztortól, de hogy az most hol lehet, nem tudja. Oidipus a népet kérdezi, tud-e valaki róla, azok azonban a királynéhez utalják. Iokasté vonakodik bármit is mondani (hiszen számára már ezen a ponton világossá válik, kicsoda is Oidipus), s a további faggatózás elől bemenekül a palotába. Oidipus azt hiszi, a királyné szégyellné,

12 Ezzel a zseniális dramaturgiával Sophoklés a legmesszebbmenőkig kiaknázza a tragikus irónia eszköztárát, és képes drámai feszültséget kelteni - annak ellenére, hogy a nézők már előre tudják, „ki a gyilkos”, hiszen Oidipus maga nem tudja. Mintha Columbo saját maga után nyomozna, anélkül, hogy tudná, ő maga a gyilkos. 
ha esetleg kiderülne férjéről, hogy alacsony származású, és ezért nem beszél, majd kijelenti, nem tart semmitől, mindenképp kinyomozza származását (924-1087).

Ez tehát a kirakós játék következő fontos darabja Oidipus számára: kiderül, hogy valóban „cserélt gyerek”, ahogy egykor hallotta, az apja nem Polybos, az anyja nem Meropé, és valami ismeretlen pásztor adta át a korinthosinak. De ki lehet az a pásztor, és kitől kapta a csecsemőt? Kik voltak a szülei? Kicsoda Oidipus?

A kirakós utolsó darabja akkor kerül elő, amikor megérkezik a thébai pásztor, aki annak idején Oidipust átadta a korinthosinak, s aki egyúttal nem más, mint Laios kísérője, aki a hármas keresztúton tanúja volt megölésének, de sikerült elmenekülnie. A pásztort Oidipus szembesíti a korinthosi hírnökkel, hogy kiderítse, valóban találkoztak-e. Az ugyan nem ismer rá a másikra, akinek egykor a csecsemőt átadta, de a korinthosi azonosítja: tőle kapta a gyermeket, aki nem más, mint Oidipus, aki előtte áll! Laios szolgája ebben a pillanatban már tudja az igazságot, hiszen tudja, Oidipus gyilkolta meg a királyt (mivel tanúja volt), s most az is kiderült számára, hogy ő nem más, mint épp az a csecsemő, akit egykor a királynétól kapott - úgyhogy minden áron ki akar térni a további kérdezősködés elől. Oidipus fenyegetőzésére azonban végül bevallja, hogy a csecsemő a királyi pár gyermeke volt, s egy jóslat miatt akarták elveszejteni. Ekkor áll össze végre a kép Oidipus számára is:

Óh, jaj, jaj! Minden tisztán napvilágra jő!

Óh napvilág! ma utoljára látlak én.

Ott születtem, hol nem kellett; azt vettem el,

kit nem lehet; s megöltem, akit nem szabad!

(1182-1185)

A rejtvényt megfejtette, a kirakós játék darabkái helyükre kerültek, s kirajzolják egy szörny arcát, aki a siker és boldogság legmagasabb csúcsairól egyszeriben aláhullt, $\mathrm{s}$ most nincs nála senki nyomorultabb - mint a Kar énekli (1186-1230).

Már csupán a tragikus végkifejlet van hátra: a palotából kijőve hírnök tudósít: Iokasté felakasztotta magát, a rátaláló, őrjöngő Oidipus pedig ruhája csatjával szúrta ki saját szemeit. A palotából véresen kilépő király a Karral párbeszédben siratja saját magát és szeretteit, majd miután Kreónra bízza gyermekei felnevelését, fájdalmasan búcsúzva tőlük önkéntes száműzetésbe indul, ezekkel a híres szavakkal foglalva össze sorsát:

Nézzetek rám: Théba népe, itt a híres Oedipus, ki a Nagy Talányt megoldta, leghatalmasabb király, minden polgár irigy szemmel leste boldogságomat:

s nézzétek, mily rettentő sors hullámába hulltam én!

Senki hát halandó embert, ki e földön várja még végső napját, ne nevezzen boldognak, mig élete kikötőjét el nem érte bánat nélkül, biztosan.

(1524-1530) 


\section{Oidipus és a tragikus hamartia}

A sors tehát beteljesedett, a gyilkos kiléte kiderült, a legtitokzatosabb rejtvényt Oidipus megfejtette - bár ne fejtette volna meg! De vajon mi volt a vétke? Volt-e vétke egyáltalán? A „vétek” (hamartia) kifejezés lényeges, hiszen Oidipus nem gonosztevő, ellenkezőleg, sok tekintetben kiváló jellem. Máskülönben a tragikus hatás nem is jöhetne létre, mint Aristotelésszel megállapítottuk. ${ }^{13}$ Jellembeli kiválóságára számos tényező utal. Legalapvetőbb módon az okossága vagy bölcsessége, hiszen megfejtette a Sphinx rejtvényét, s ezzel megmentette egész Thébát. Uralkodóként is kiváló, minthogy elszántan kutatja Laios gyilkosát, hogy megmentse népét; ebben nem csupán királyi felelősségérzete hajtja, hanem tudásvágya is, ahogy annak idején hajtotta, mikor felmerült a legcsekélyebb gyanú, hogy „cserélt gyerek”, s ő azonnal utána akart járni az igazságnak. Nem utolsósorban pedig erkölcsi felelősségérzete, hiszen mikor meghallja a jóslatot, hanyatt homlok menekül, nehogy elkövesse szülei ellen ama szörnyü bűnöket. Mi tehát a vétke? Miben hibázott?

A történet dramaturgiájának alaposabb vizsgálata feltárja, hogy bár Oidipus figyelemre méltó elszántsággal veti bele magát a gyilkos utáni nyomozásba, ebben mintha mégsem járna el megfelelő körültekintéssel. Amikor Iokasté a jóslatok megbízhatatlanságával nyugtatgatja, és elejti a kirakós játék első darabját (a keresztút említésével), Oidipus elsiklik néhány fontos részlet felett (707-738). Ezen a ponton annyit tud, hogy 1) egy előkelő idős úrt megölt egy hármas keresztútnál (szolgáival egyetemben), aki úgy nézett ki, ahogy Iokasté leírta Laiost; 2) a királyt és kíséretét állítólag több útonálló gyilkolta meg, de az egyik szolga elmenekült, ő vitte a hírt Thébába a gyilkosságról; 3) ez a szolga azt kérte a királynétől, hogy elmehessen a hegyekbe pásztorkodni, amint Oidipus trónra került; 4) a gyilkosság nem sokkal azelőtt történt, hogy Oidipus Thébába ért; 5) Iokasté és Laios gyermekét csecsemőkorában kitették és bokáit átszúrták; 6) saját származása bizonytalan (hiszen erre nem kapott annak idején választ Apollóntól).

Ez meglehetősen sok információ, azonban Oidipus csupán arra koncentrál - ami persze a leglényegesebb - hogy talán ő volt az, aki megölte Laiost (725-748, 814-856) (1 alapján). Ám számos egyéb körülmény felett elsiklik. Elgondolkodtató például a furcsa egybeesés, hogy nem sokkal Laios meggyilkolása után érkezett Thébába (4); ugyanígy az is, hogy a kísérő, aki szemtanúja volt a király megölésének, közvetlenül azután elhagyta a palotát, hogy Oidipus trónra került (758-764) (2 és 3). Csak nem azért, mert fölismerte benne Laios gyilkosát? További, még erősebb gyanakvásra adhatna okot szá-

${ }^{13}$ Miután Aristotelés rámutat, hogy sem az erényesek, sem a hitványak szenvedése nem tragikus, így folytatja: „Marad tehát az, aki ezek között van. Az ilyen pedig az, aki erénye és tisztessége folytán nem emelkedik ki, de nem is alávalósága és gonoszsága miatt váltott át balsorsba, hanem valamilyen tévedése (hamartia) folytán, valaki a dicsőségben és jó sorsban levők közül, mint például Oidipusz vagy Thüesztész vagy az ilyen családokból való kitűnő férfiak" (Arist. Po. 1453a7-12, Ritoók Zsigmond fordítása). A hamartia ('hiba', 'tévedés', 'vétek') főnév a hamartanó igéből származik, melynek alapjelentése: 'elvéti a célt' (főként lándzsával); innen származnak az ige további jelentései: 'hibázik', '(célját tekintve) kudarcot vall, 'vétkezik' (LSJ s.v.

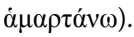


mára, hogy miközben Laios és Iokasté gyermekét csecsemőkorában kitették, az ő származása bizonytalan (6). Mi van, ha az a csecsemő történetesen nem halt meg, ehelyett elkerült Korinthosba a királyi párhoz, s ő maga az? Azonban a legelgondolkodtatóbb részlet, mely felett Oidipus túl könnyedén napirendre tér, nem más, mint a kitett csecsemő átszúrt bokája (5). Talán nem elgondolkodtató egybeesés, hogy a kitett csecsemővel így bántak, neki pedig gyermekkorától fogva szintén sérült a lába - sőt, erről kapta a nevét, amint azt a korinthosi pásztor később fel is idézi (1032-1036)?

Úgy vélem, ez nem valamiféle dramaturgiai melléfogás Sophoklés részéről, ellenkezőleg: azt kívánja érzékeltetni, hogy a figyelmetlenség nem véletlen, ugyanis megvilágítja Oidipus jellemének és sorsának összefüggését. Oidipus - ezt a néző pontosan látja - nincs tudatában saját (valódi) identitásának, ám ami még fontosabb, nem is akarja tudomásul venni, bármilyen elszántan kutatja is egyébként „a gyilkost”. ${ }^{14}$ Identitását alapvetően meghatározza egy fizikai sérülés, fogyatékosság, melyről - úgy tűnik - hajlamos megfeledkezni. A sérülésnek egzisztenciális jelentősége van: fogyatékossága az emberi esendőség kézzelfogható jele ${ }^{15}$ de egyúttal szimbóluma is, Oidipus valódi identitásának meghatározója: ő valójában az a csecsemő, akit egykor eltaszítottak, kitaszítottak, nem az, akinek hiszi magát (a korinthosi királyi pár fia); nem a „mindentudó” szerencsefia, aki megfejtette a Sphinx rejtélyét, Théba dicsőséges királya ${ }^{16}$ - akinek tehát látszik saját maga és mások előtt. Látszat és valóság, illúzió és tudás gyökeres ellentmondásban állnak: Oidipus végzetes tévedés áldozata. Így a tragikus fordulat és felismerés, a tragikus irónia abban áll, hogy valódi identitása épp az ellenkezője annak, amit hitt magáról és amit róla hittek: nem „az emberek elseje”, nagyhatalmú, boldog tyrannos, hanem a legalávalóbb szerencsétlen, az állam rákfenéje, pharmakos (kitaszítandó bűnbak). ${ }^{17}$

14 Oidipus egészen a korinthosi hírnök/pásztor és a thébai szolga/pásztor szembesítéséig (amikor az előbbi tanúsítja, hogy ő kapta a csecsemőt a thébaitól és vitte a korinthosi királyi párhoz, az utóbbi pedig azt, hogy a csecsemőt Iokastétól kapta a Laiosnak adott jóslat miatt) ragaszkodik a (hamis) hithez, hogy Polybos és Meropé fia, holott Apollóntól nem kapott választ származására, csak a szörnyű jóslatot kapta. Laiosban érdekes módon azonban fölmerül a gyanú, évekkel a csecsemő kitétele után, hiszen Delphoiba indul, hogy megtudakolja, él-e még (vö. 10. j.). Azt mondhatnánk, hogy Laios Oidipus elnyomott tudatalattiját reprezentálja: ő az, aki számol a valószínűtlen (de nem kizárható) lehetőséggel, hogy a csecsemő életben maradt. Ezt azonban soha nem tudja kideríteni, ugyanis Oidipus (a tudatos én) meggyilkolja.

${ }^{15}$ Erről lásd Th. Dethlefsen: Oidipusz, a talány megfejtője. Ford. Sarankó Márta. Budapest (1997) 90-91.

${ }^{16}$ Igen erős drámai hatást kiváltó szavak, amikor Iokasté már tudja, kicsoda Oidipus, majd elrohan (hogy - mint később megtudjuk - öngyilkosságot kövessen el), és Oidipus így kiált fel: „Jöjjön, aminek jönnie kell! Meg akarom / ismerni származásomat, ha koldus is! / Iokasté tán, mert minden asszony nagyranéz, / szégyellni fogja alacsony családomat. / De én a sors fiának vallom magamat, / ki minden jót ad és pirulni nem fogok. / Az én anyám a Sors volt, és testvéreim / a hónapok, akikkel nőttem s fogytam én. / Az vagyok, aki vagyok. Úgyse lehetek / más: mért féljek hát fölfödözni, ki vagyok?” (1078-1087)

17 A király és bűnbak kettősségének szimbolikájáról, valamint a görög bűnbak-rituálé relevanciájáról a tragédiában lásd Vernant: $i$. m. (4. j.) 124-136. 
Ám Oidipus vétkes figyelmetlensége jellemhibáit tekintve még nem minden: a probléma gyökere mélyebb. Egy szempontból igencsak hasonlatos a görögök legnagyobb hőséhez, Achilleushoz. Emlékezzünk az Ilias első szavára:

Haragot (ménin), istennő, zengd Péleidész Akhileuszét, vészest, mely sokezer kínt szerzett minden akhájnak...

Oidipus jellemét hasonlóképp meghatározza az indulatosság, düh vagy harag (orgé $\left.e^{18}\right)$, $\mathrm{s}$ ami ezzel gyakorta együtt jár, az elhamarkodott ítélőképesség. A harag az erős önérzet sérelmének emocionális kifejeződése, az elismerés hiányának, és/vagy a dolgok, személyek helyzetek kontrollálhatatlanságának érzése. A harag motiválja Oidipust, amikor leparancsolják a keresztútról (807), de dühös lesz akkor is, amikor borközi állapotban "cserélt gyereknek” nevezik (781). Ez igencsak fontos tényező, ha egyszer ez vezet a gyilkossághoz (807). Már az is érthetetlen, vajon mitől gurult be oly mértékig, hogy pillanatok alatt végzett négy emberrel, csak mert egy szúk útról gyalogosként leparancsolták. Lobbanékony természete azonban Teiresiasszal és sógorával/nagybátyjával, Kreónnal szemben nyilvánul meg a legszembeszökőbb módon, a darab elején.

Oidipus fergeteges haragra gerjed, amikor Teiresias enigmatikus beszédéből megsejti, hogy az tud valamit, de vonakodik elárulni (334-349). Mikor pedig a végletekig provokált Teiresias végül fejére olvassa, hogy ő maga a gyilkos, akit keres és fertőben él (362-367), rögtön összeesküvés-elméletet gyárt, miszerint csak arról lehet szó, hogy Kreón bérelte fel a jóst, hogy kenje rá a gyilkosságot, mert irigyli a trónját, $\mathrm{s}$ a rágalommal el akarja távolíttatni (378-403). Kreón éppúgy megdöbben ettől a légből kapott gyanúsítástól, mint a Kar vagy Iokasté (513-532, 608-617, 635-649). A megmagyarázhatatlan harag végzetesen elhomályosítja Oidipus józan ítélóképességét (gnómé, phronésis) - ahogy az már csak lenni szokott erős emóciók esetén..$^{19}$ Ennek fényében arra kell következtetnünk, hogy a nyomozás során elkövetett vétkes figyelmetlenség sem véletlen: szoros összefüggésben áll Oidipus indulatos természetével.

Vajon honnan ered az indulatosság, specifikusan a harag? Figyeljünk fel rá, hogy az összeesküvés-elmélet Apollón Teiresias által elejtett neve hallatán „kattan be” Oidipusnak (376-377). Persze elsősorban az a gyanú merül fel benne, hogy Kreón hazudott

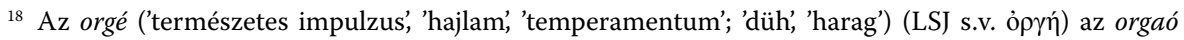
igéből képzett főnév, melynek jelentései: '(tápanyaggal, nedvekkel) telített', 'dagadó, 'érett (föld, gyümölcs)'; 'vágytól duzzadó, buja (férfi)'; 'tüzel,' 'szexuális izgalomban van (ember, állat)'; 'tettre kész', 'izgatott', 'szenvedélyes' (R. Beekes: Etymological Dictionary of Greek. Leiden - Boston [2010] Vol. 2. s.v. ỏ $\rho \gamma \alpha ́ \omega, 1097)$. A görögök tehát a haragot a szexuális izgalomhoz hasonlatos, ellenállhatatlan vágyként fogták fel, mely vakon törekszik rá, hogy valamilyen tárgyon kielégülést nyerjen - akár például úgy, hogy a haragvó valakit alaptalanul megvádol, ahogy Oidipus teszi Teiresiasszal.

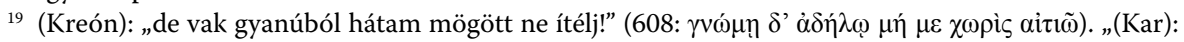

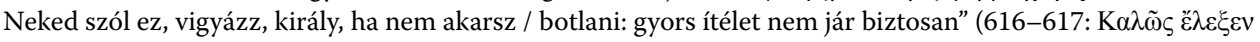

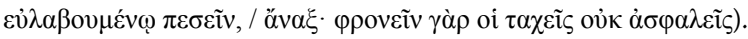


Apollón tanácsával kapcsolatban (ti. hogy találják meg Laios gyilkosát) (95-101), s közben összeszövetkezett a jóssal, hogy az vádolja meg őt a gyilkossággal (vö. 533-543). ${ }^{20}$ Ám Apollón nevének tudat alatt fel kell idéznie Oidipus számára a legnagyobb rejtélyt is, mellyel dolga volt és van, azaz a neki adott szörnyü jóslatot. Az irracionális harag ereje innen magyarázható. Oidipusban haragnak kellett ébrednie Apollón jóslatával kapcsolatban (is), mivel önérzetében, önbecsülésében érezte sértve magát. És valóban, saját megfogalmazása szerint Apollón nem méltatta válaszra arra vonatkozóan, ami felől kérdezte, nevezetesen származása, szülei felöl. ${ }^{21}$ Ehelyett szörnyüséges dolgokat jósolt a jövőjére vonatkozóan.

Ez azonban még korántsem minden, ami Oidipus delphoi jóslathoz való viszonyáról elmondható. A jóslat ugyanis olyasmit jelentett ki, ami nemcsak meglepte és megsértette, hanem rejtélyessége okán végtelen zavarba is hozta. Ôt, a rejtvények utolérhetetlen megfejtőjét! Felvethető, hogy Oidipus önérzete kognitív képességeire vonatkozóan a legerősebb, így ez az a pont, ahol bármiféle sérelem vagy lekicsinylés a legmélyebben érinti. Amikor Teiresias azt sejteti, hogy többet tud nála, sőt olyasmit, aminek egyáltalán nincs tudatában, összeesküvés-elméletével lesöpri a színről, vádaskodni kezd vele szemben, s gőgösen kétségbe vonja a jós isteni képességeit a saját eszével szemben:

Szólj hát ugyan, hol az a híres jóserőd?

Mért nem tudtál, mikor itt volt a dalnok eb,

a városnak valami mentőt mondani?

Nem jövevénynek illett bizony a talányt

megoldani: az jóslás dolga volt, amit

te sem madárból nem látszott, hogy értenél,

sem isten-ihletésből; akkor jöttem én,

én, a tudatlan Oedipus, s megoldtam azt

pusztán eszemmel (gnómé), nem madárjelek szerint.

(390-398)

${ }^{20}$ Sőt, egy ennél még meredekebb összeesküvés-elmélet is körvonalazódik később Kreónhoz intézett kérdéseiből: lehetséges, hogy annak idején Kreón tervelte ki Laios meggyilkolását, mert már akkor a trónra tört, és lebeszélte róla Teiresiast (akinek már akkor tudnia kellett, hogy ki volt a gyilkos), hogy felfedje az igazságot (558-569). Vö. J.-P. Vernant: Oedipus without the Complex. In: Vernant - Vidal-Naquet: i. m. (4. j.) 106. Mint itt Vernant rámutat, Oidipus saját hatalomvágyát vetíti ki Kreónra, akinek azonban esze ágában sincs királynak lenni, ha egyébként minden terhes felelősség nélkül élvezheti előjogait (OT 583-628). A hatalomvágy a helyzetek, emberek, események feletti kontroll vágya. A harag egy fajtája pedig az efféle vágy kielégülésének lehetetlenségéből táplálkozik.

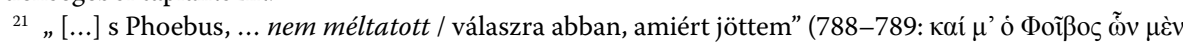

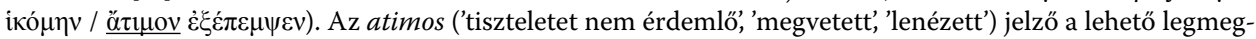
alázóbb, legkiszolgáltatottabb társadalmi státuszra utal az V. századi görögség szótárában (vö. Pl. Grg. 486c1). Oidipus megfogalmazása tehát világosan utal önérzete mély sértettségére, s ezen keresztül Apollónnal szembeni (elfojtott) haragjára. 
Ez a gőg sodorja hát bajba Oidipust kezdettől fogva, ebben áll a hybris ('gőg', 'önteltség', 'elbizakodottság'), ebben a vétke. Amikor Apollóntól Delphoiban azt hallja, hogy anyjával fog hálni és megöli az apját, majd hanyatt-homlok menekül (csak ne kelljen Korinthosba visszatérnie), biztosra veszi, hogy tudja, ki az anyja és az apja. Holott épp azért indult a jósdába, mert a kocsmában valaki elszólta magát, hogy tán nem is azok a szülei, akiket annak vél, így hát ki akarta deríteni valódi származását. Apollóntól nem kapott választ a kérdésre, ám ehhez képest nyomozása alatt a végsőkig ragaszkodik hozzá, hogy tökéletesen tudatában van származásának. Mi ez, ha nem kognitív nárcizmus, Oidipus saját tévedhetetlenségébe, esze (értelme, ítélőképessége) omnipotenciájába vetett illuzórikus hite? A tragikus irónia ebben áll: Oidipus, aki tudta, hogy a Sphinx rejtvényére a válasz „az ember”, valójában nem tudja ki az ember, mert nem ismeri saját magát. Nem tudja (oida), kicsoda az a „kétlábú lény” (dipous), a sérült lábú, aki nem más, mint saját maga. ${ }^{22}$ Ugyanis önnön bölcsessége tévedhetetlenségébe és mindenhatóságába vetett hite elhomályosítja esendőségét.

Sophoklés legalapvetőbb üzenete tehát Oidipus sorsával az, hogy az ilyen hit életveszélyes, tragédiába sodorhat, mégpedig nem csupán az érintettet, hanem a rábízottakat (akár a szeretteit) is. Főként életveszélyes egy uralkodó számára, hiszen „fejétől büzlik a hal": az uralkodó (király) hybrise kiterjed a birodalmára is (innen a várost sújtó pestis). Ez az üzenet különösen Sophoklés korában releváns, amikor az autonóm emberi értelembe és az általa elért haladásba vetett hit felerősödik. ${ }^{23}$ Sophoklés perspektívájából nézve nem az a probléma, hogy az ember hisz saját eszének erejében és képességeiben, hanem az, ha egyenesen tévedhetetlennek s ezen keresztül mindenhatónak képzeli magát - akár önnönmaga, akár mások, akár mindkettő felett. ${ }^{24}$

Amikor Apollóntól megkapja a jóslatot, Oidipusnak igencsak óvatosan kellene eljárnia, ugyanis Delphoi jóslatai hírhedten enigmatikusak vagy ambivalensek. Főként azok, amikor hírességek vagy hatalmasságok fordulnak hozzá tanácsért, eligazításért. Van olyan nézet, miszerint ennek az a magyarázata, hogy megvédte Delphoit a hatalmasságok bosszújától: ha így is, úgy is lehetett érteni, amit a papnő kijelentett, végül mindig a jóslatkérőt lehetett hibáztatni a félreértelmezésért. ${ }^{25}$ A delphoi Apollón jóslatai azonban gyakorta a hatalmasságok egyfajta erkölcsi tesztjeként funkcionálnak, azt kívánják lemérni, és saját bőrön tapasztalt leckével megtanítani, hogy ne teljenek el ma-

22 Vö. Vernant: $i . m$. (4. j.) 124.

${ }^{23}$ Vö. A.-B. Renger: Oedipus and the Sphinx. The Threshold Myth from Sophocles through Freud to Cocteau. Chicago - London (2013) 44.

${ }^{24}$ A drámában Kreón és a nép (a Kar) képviselik a megfelelően józan, hybris-mentes hozzáállást. Lásd különösen a következőket: „Kar: Nem hiszem / és nem tagadom: mit tudom én, / mi az igaz?” (485-486: oű $\varepsilon$

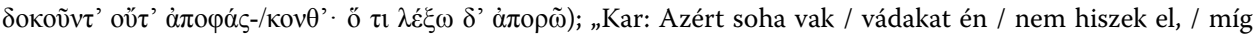

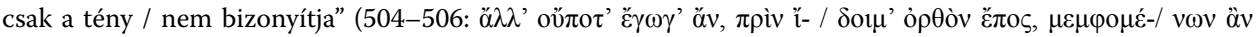

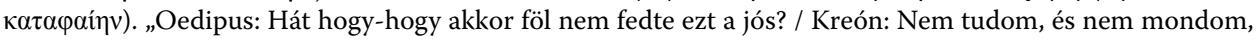

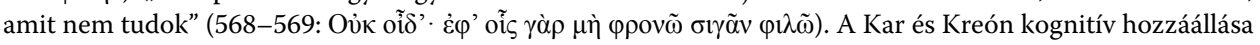
egyenesen sókratési. (Erről lásd alább.)

${ }^{25}$ M. Scott: Delphi: A History of the Center of the Ancient World. Princeton - Oxford (2014) 19. 
guktól, ne essenek a hybris vétkébe: „ismerd meg tenmagadat!” (gnóthi seauton). Ami annyit tesz: ismerd fel határaidat, ember, ne véld istennek magad, hiszen csupán esendő ember vagy, nem több: „porból lettél, porrá léssz”. Amit Oidipus büszkén vág Teiresias arcába („megoldtam azt, / pusztán eszemmel, nem madárjelek szerint” 397-398), világosan jelzi, mi is a gond: amikor az ember a saját eszét - az isteni bölcsességgel szemben - mindenhatónak (isteninek) véli, végzetes hibát (hamartia) követ el, melynek csak tragédia lehet a következménye.

A tragédia bizonyos értelemben elkerülhetetlen Oidipus számára. Nem azért, mert az istenek determinálják, hanem mert épp olyan jellemmel rendelkezik, amilyennel, és sorsa szoros összefüggésben áll vele. ${ }^{26} \mathrm{~A}$ jellem azonban alakítható, ha egyszer „hibáról” (hamartia) van szó. Elvileg nem kizárható, hogy valaki ne hibázzon, ha elég óvatos, ha odafigyel, ha reflektál saját magára, ha képes távolságot tartani magától, elsődleges impulzusaitól, hajlamaitól, szenvedélyeitől, vágyaitól. ${ }^{27}$ De legfőképp, ha nem képzeli csalhatatlannak, tévedhetetlennek, tökéletesnek - istennek - önmagát. A szenvedély megregulázható, ha az ember elismeri saját esendőségét, végességét, bölcsessége határait, mégpedig elsősorban önmaga előtt. Erre ugyanis senki más nem kényszerítheti, hacsak nem a valóság, melybe előbb-utóbb kényszerűen, sorsszerüen beléütközik - miként Oidipus.

Oidipus pendantja a görögség történetében Sókratés. Mégpedig nem imaginárius megfelelője, hanem valóságos. Ami azt jelenti: nem illuzórikus a condition humaine meghaladása, hanem reális lehetőség. Sókratésnek sikerült - nem istenként, hanem egyszerű emberként. Úgyhogy nincs felmentésünk: az imitatio Socratis mindenki előtt nyitva áll.

\section{Sókratés és a filozófiai katarzis}

Mint utaltam rá, Sókratést Oidipushoz hasonlóan bölcsnek (sophos) tartották kortársai, habár - Platón ábrázolásában - ez perében éppenséggel negatív felhangokat kapott. ${ }^{28}$ Amennyiben ez az egyébként hagyományosan evidens módon dicsérő kifejezés az V.században negatív konnotációkat vehetett fel, annak oka pontosan az, amiért Oidipus

${ }^{26}$ Sors és jellem összefüggésére vonatkozóan ismét Aristotelés igazít el bennünket. Habár azt állítja, a jellem a cselekményhez képest alárendelt szerepet játszik (Po. VI. 1450a15-25, 38-39), azt is állítja, hogy a jellem határozza meg a tragikus hős választását (proairesis) (Po. VI. 1450b8-9) - tehát ezen keresztül a cselekményt is. Noha ez vitatott kérdés, ennek alapján úgy vélem, a cselekményben megnyilvánuló jellem játszik kulcsszerepet a tragikumban. Heller Ágnes hasonlóképp a jellemnek tulajdonít elsődleges fontosságot a görög tragédiában (az elterjedt közhellyel szemben, miszerint a görög tragédiában a sors, a modern tragédiában a jellem az elsődleges): Heller Á.: Tragédia és filozófia. Párhuzamos történet. Budapest (2021) 48.

27 A szenvedélyt (specifikusan a haragot) és a józan ítélőképesség hiányát a Kar világosan összefüggésbe hozza: „Csak indulat csikarta tán belőle ki / a gyanusítást, nem volt meggondolt beszéd” (523-524: 'A $\lambda \lambda$ '

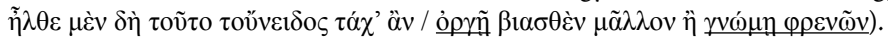

${ }^{28}$ Ezt a jelzőt aggatták rá ugyanis az őt rágalmazók (vö. Pl. Ap. 18b-c, 23a). 
oktalannak tekinthető: nem számol az istenekkel. ${ }^{29}$ Akiknek az volt az érdeke, hogy Sókratést „istentelennek” tekintsék az athéniak, amikor felette ítélkeztek a bíróságon, könynyü volt informális jogalapot gyártaniuk erre azzal, hogy elterjesztették: Sókratés olyasféle ateista bölcs (természetfilozófus), mint Anaxagoras, aki „a Napot kőnek mondja, a Holdat meg földnek” (Pl. Ap. 26d). Ez az a rágalom, mellyel szemben Sókratés először védekezik, ugyanis úgy véli - teljes joggal - hogy mélyen meghatározza az athéniak róla kialakult képét. ${ }^{30}$ Ebben az értelemben Sókratés semmiképp sem tartja magát bölcsnek, hiszen nem foglalkozik természetfilozófiával (Ap. 19a-d). Amikor azonban emellett azt is meg akarja magyarázni, hogy egyáltalában miért terjedhetett el róla ez az elnevezés, egy olyan történettel áll elő, mely nemcsak ezt magyarázza meg, hanem megvilágítja egész, Athénban folytatott tevékenységének természetét is, mely bajba keverte. Nem utolsósorban pedig egészen más megvilágításba helyezi „bölcsességét” is. Ez a híres delphoi jóslat története $(A p .20 \mathrm{e}-23 \mathrm{c}) .{ }^{31}$ Ennek a történetnek itt csupán az az aspektusa érdekes számunkra, melyben megragadható a kontraszt Oidipus saját jóslatára adott reakciójával, s egyúttal megmagyarázhatja a tragikus és az anti-tragikus hős, illetve a tragikus és a filozófiai katarzis közötti különbséget is. A történet jól ismert, ezért csupán röviden foglalom össze.

Sókratés egy lelkes híve, Chairephón egyszer elment Delphoiba, hogy megkérdezze, van-e Sókratésnél bölcsebb ember. A Pythia azt felelte, hogy nincs. Sókratés a kijelentéstől mélyen zavarba jött, ugyanis egyfelől úgy gondolta, egyáltalán nem bölcs, másfelől azonban hitte, hogy az isten nem hazudik. Jó ideig nem talált kiutat ebből a dilemmából, de végül kisütötte, hogy elmegy egy bölcs hírében álló emberhez, hogy ott megcáfolja a kijelentést: bebizonyítja az istennek, hogy igenis van nála bölcsebb ember. Sorra megvizsgálta ${ }^{32}$ hát a korban bölcsnek tartottakat (államférfiakat, költőket, mesterembereket), de mindannyiszor az derült ki, hogy habár sokan bölcsnek gondolják őket, s persze a leginkább annak tartják saját magukat, de valójában egyáltalán nem azok: vagy nem tudnak semmit (államférfiak), vagy ha tudnak, csupán isteni ihletettségben alkot-

${ }^{29}$ Lásd különösen Teiresiashoz intézett, fent idézett szavait (390-398). Oidipus ironikus megjegyzésének értelme, hogy a jós isteni ihletettségű képességei mit sem érnek az ő emberi eszéhez képest. A tragikus irónia viszont, hogy dehogynem!

30 Platón percepciójában ehhez persze hozzájárult Aristophanés komikus portréja a Felhőkben, ám nem ez vezetett Sókratés elítéléséhez, hanem „a névtelen rágalmazók” (ti. akiket Sókratés elenchtikus módszerével megvizsgált) vádaskodásai (vö. Ap. 18a-e). (A módszerre vonatkozóan vö. 32. j.)

31 A jóslatról Xenophónnál lásd Ap. 14. 5-9.

32 A vizsgálódás feltehetőleg a híres sókratési elenchos ('vizsgálat,' 'cáfolat') keretében zajlott, melyet föként a korai platóni dialógusok (pl. Lachés, Lysis, Euthyphrón, Gorgias) mutatnak be. Ennek lényege, hogy Sókratés megpróbálja rávenni beszélgetőpartnerét, hogy szabatosan határozzon meg egy adott erényt (általában olyat, ami releváns az adott partner életében vagy élethelyzetében), majd a javasolt definícióhoz szorosan kapcsolódó kérdések és feleletek során kiderül, hogy a beszélgetőpartner bizonyos nézetei (rejtett előfeltevései) között ellentmondás áll fel, így a partner a dialógus egy pontján (vagy a végén) teljes zavarba (aporiába, 'gondolati kiúttalanságba') kerül, mivel két (vagy több) egymásnak ellentmondó nézete közül egyiket sem hajlandó feladni. Innen általában nem lépnek tovább (a definiendum kielégítő meghatározása felé), mindenesetre a definícióról legalább kiderül, hogy tarthatatlan, hiszen ellentmondásokat rejt magában. Lásd még 47.j. 
nak, és nem képesek számot adni a tudásukról (költők), vagy értenek ugyan bizonyos dolgokhoz, de emiatt azt hiszik, az emberi élet legfontosabb kérdéseire vonatkozóan is tudással rendelkeznek (mesteremberek). Sókratés már az első államférfiú megvizsgálása után fölismeri, hogy bizonyos értelemben bölcsebb nála: míg az előbbi azt hiszi, tud valamit, miközben nem tudja, Sókratés nem hiszi, hogy tudja, amit pedig nem tud (21d). Ez a következtetése minden további vizsgálódással csak megerősítést kap: akár tudással rendelkezett valaki, akár nem, mindenki elkövette a hibát, hogy azt hitte, tud valamit, miközben valójában - ez Sókratés kérdezősködései nyomán derült ki - nem tudta. Így hát Sókratés végül levonta az általános konklúziót: úgy tűnik, annyival mégiscsak bölcsebb másoknál, hogy ha valamit nem tud, arról nem is hiszi, hogy tudja (Ap. 23a-b). Úgyhogy a jóslat nem azt állítja, hogy ő a szó legteljesebb értelmében véve bölcs (mindentudó) volna ${ }^{33}$ - hiszen ebben az értelemben „egyedül az isten bölcs” (Ap. 23a5-6) -, hanem csupán például állítja őt mások elé, mintegy azt üzenve nekik: „Emberek! Az közöttetek a legbölcsebb, aki Sókratéshez hasonlóan fölismerte, hogy bölcsesség tekintetében igazság szerint semmit sem ér" (Ap. 23b2-4).

Platón átgondolt megfogalmazásában több tényező is világosan utal rá, hogy a történet értelmezésekor érdemes felidéznünk a hagyományos delphoi jóslatok természetét, főként azt, ahogyan a jóslatkérő értelmezi a jóslatot, illetve azt, ami az értelmezés után történik vele. ${ }^{34} \mathrm{~A}$ jóslatok egy bizonyos fajtájának (ti. a homályos, rejtvény jellegü jóslatoknak) ugyanis rendkívüli, egzisztenciális jelentősége van: „Az archaikus kultúrában a rejtvény eredetileg nem szórakoztató időtöltés, hanem halálos viadal. A thébai Szfinx azért öli meg az embereket, mert nem tudják megfejteni rejtvényét a lényről, amely majd négy, majd két, majd pedig három lábon jár. Amikor Oidipus megfejti a rejtvényt: az ember ez a lény - akkor a Szfinx leveti magát sziklájáról, és szörnyethal. A legenda szerint Homérosz halálát is az okozta, hogy nem tudta megfejteni a tetü-rejtvényt. A rejtvény mint halálos játék különösen alkalmas arra, hogy az emberi sors megjelenítésére szolgáljon: aki nem érti vagy félreérti a sorsát, veszít." ${ }^{35}$

A Sókratésnek - pontosabban Chairephónnak - adott jóslatban látszólag semmi rejtélyes vagy rejtvényszerű nincs: a jelenre vonatkozó, világos kijelentésnek tűnik: nincs Sókratésnél bölcsebb ember. ${ }^{36}$ Mégis, Sókratés számára nagyon is enigmatikus és egyáltalán nem egyértelmű a mondandója. Mármost, amiért Sókratés megfejtendő rejt-

33 A sophos az istenekre vonatkozóan 'mindentudót' jelent, ami nyilvánvalóan egyetlen emberre nézve sem igaz (vö. Pl. Sph. 233a-c). Vö. Mogyoródi E.: Szókratész, a „visszhangkamra” és a demokrácia. In: Laczkó S. (szerk.): Lábjegyzetek Platónhoz 17: A polisz. Szeged (2019) 19, 22. j. és 41. j.

${ }^{34}$ A delphoi jóslatoknak persze több típusa létezett - az egyszerü parancstól a jövőre vonatkozó állításig -, bennünket azonban itt a jóslatadás és a jóslathoz való viszonyulás bizonyos általános tendenciái érdekelnek. A típusokra vonatkozóan lásd Steiger K.: A delphoi jóslatokról. In: Delphoi jóslatok. Válogatta, fordította és utószóval ellátta Steiger Kornél. Budapest (1992) 61-80. Ilyen, általános tendencia egyfelől, hogy a jóslat világos-e vagy homályos (egyfajta rejtvény, mely értelmezésre szorul), illetve hogy összefüggésben áll-e (s ha igen, mennyiben) a jóslatkérő jóslatot követő sorsával („sorsorákulum” vö. Steiger: i. m. 66).

35 Steiger: $i$. $m$. (34. j.) 70.

36 Steiger Kornél így is sorolja be: Steiger: $i . m$. (34. j.) 62 . 
vényként, nem pedig ténykijelentésként fogja fel a Pythia szavát, annak oka, hogy - a kinyilatkoztatással gyökeres ellentétben - egyáltalán nem hiszi magát bölcsnek:

Mert miután e szavakat meghallottam, mélyen elgondolkodtam (enethymumén), valahogy így: Mit is mond az isten, miféle rejtett értelme van a szavának (ti pote ainittetai ${ }^{37}$ )? Hisz legjobb tudomásom szerint (synoida emautói) én bizony sem nagyon, sem kicsit bölcs nem vagyok. Akkor hát mit akar mondani, amikor kijelenti, hogy én vagyok a legbölcsebb ember? Mert, gondolom, csak nem hazudik. Hisz ezt az isteni törvény neki meg nem engedi. (Pl. Ap. 21b2-7) ${ }^{38}$

Az tehát, hogy Sókratés nem tudja ténykijelentésként értelmezni a delphoi szót, abból a meggyőződéséből fakad, hogy nem bölcs. Ez pedig éppenséggel a delphoi intés, a hybristől való tartózkodás megszívleléséből ered, mely Sókratés számára egyfajta lelkiismereti kérdés, ${ }^{39}$ hiszen meggyőződése, hogy „egyedül az isten bölcs”. ${ }^{40}$ Mély dilemmája tehát egy olyan ellentmondásból fakad $(\mathrm{C} 1, \mathrm{C} 2)$, mely ugyanarra a premisszára $(\mathrm{P} 1)$ vezethető vissza:

P1: „egyedül az isten bölcs” (Ap. 23a5-6 $)^{41}$

C1: Sókratés nem bölcs

P2: a delphoi isten (aki bölcs: P1) kijelentése szerint „Sókratés bölcs” (Ap. 21a6-7)

C2: Sókratés bölcs

Az ellentmondás azért olyan gyötrő, mert egyetlen premissza a gyökere (P1), ${ }^{42} \mathrm{~S}$ valóban csak úgy lehet feloldani, ha a Sókratésre vonatkozó „bölcsesség” a két konklú-

${ }^{37}$ Ebből az igéből derül ki, hogy Sókratés a kijelentést rejtvényként fogja fel. Az ainigma ('homályos beszéd,' 'rejtvény') főnév az itt használt ainittomai ('homályosan, rejtvényekben beszél') igéből ered.

38 A Sókratés védőbeszédét a továbbiakban is saját fordításomban közlöm (vö. 43. j.).

39 A fenti passzusban az enthymeomai ('meggondol,' 'megszívlel', 'megfontol,' 'törődik valamivel,' 'aggódik valami miatt', abs. 'gondolkodik') ige, de különösen a synoida emautói ('tanúként tud/ismer valamit', 'tudatában van valaminek'; itt: 'tudja magáról, hogy...) kifejezés egyfajta mély magábaszállásra, lelkiismeret-vizsgálatra utal. Erről bővebben lásd Mogyoródi E.: Sókratés és a (jó) lelkiismeret. AntTan 52 (2008) 185-189.

${ }^{40}$ Nem véletlen, hogy nem Sókratés kérdezte a jósdát, van-e nála bölcsebb ember, hanem ügybuzgó barátja, Chairephón. Sókratés magát a kérdést is hybrisnek tartja: „Így azután egyszer még Delphoiba is elment, és odáig merészkedett (etolmése), hogy a következőt kérdezte a jósdától..” (Ap. 21a4-5). Mint Steiger Kornél a Kroisosnak adott híres jóslat kapcsán („ha átkelsz a folyón, nagy birodalmat döntesz meg”) mély értelműen megjegyzi: „A történetből az is kiviláglik, hogy nemcsak a jóslat értelmezéséhez, de magához a helyes kérdés feltevéséhez is önismeret szükségeltetik" (Steiger: $i$. m. [34. j.] 76). A delphoi intés (gnóthi seauton) jelentőségére vonatkozóan Sókratés számára lásd Phdr. 229e-230a.

41 Itt Sókratés vagy generikus értelemben használja „az isten” kifejezést, vagy egyenesen a delphoi istenre (Apollónra) gondol. Apollón bölcsessége (mindentudása) tehát mindenképp implikált. Apollón mindentudásáról már a homérosi Hermés himnusz tanúskodik (h.Merc. 533-538).

42 Sókratés tehát maga is aporiába kerül, épp a delphoi jóslat miatt (vö. 32. j.): sem C1-et, sem C2-t nem tudja elvetni, mert mindkettőt igazként tételezi. Az aporia helyzetét a delphoi jóslat sókratési értelmezésében Platón nyelvileg is aláhúzza: „Azután jó ideig kétségek közt hányódtam, hogy mit is akar mondani...”

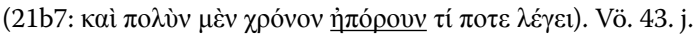


zióban (C1 és $\mathrm{C} 2$ ) eltérő értelmű. C1-ben nyilván ugyanabban az értelemben szerepel, mint P1-ben, ti. a mindentudás értelmében (hiszen C1 P1-ből közvetlenül következik). C2-ben azonban más jelentése van - $\mathrm{s}$ ez az, amit Sókratés vizsgálódásai során kiderít: az a bölcs, aki tudatában van saját tudása limitált voltának, ugyanis tudja/elismeri, hogy nem mindentudó. ${ }^{43}$

Ebből azonban további meglepő következtetések adódnak. Ezek szerint Sókratés már akkor bölcs volt abban az értelemben, ahogyan végül megfejtésekor értelmezi a bölcsességet, mielőtt megfejtette volna a jóslatot. Hiszen már akkor hitte, hogy nem bölcs (nem mindentudó), amikor a Pythia bölcsnek nyilvánította. Ha nem hitte volna, hanem szó szerinti értelemben vette volna a kinyilatkoztatást, akkor bizony a legnagyobb ostobaságot követte volna el, és a hybris vétkébe esett volna. Hiszen semmibe vette volna az alapvető delphoi intést, hogy az ember ne gondolja magát bölcsnek, mivel „egyedül az isten bölcs”. Így Sókratés delphoi jóslata egyfajta önbeteljesítő jóslatnak bizonyul: mivel Sókratés nem hiszi, hogy bölcs, ezért nem hiszi el a kinyilatkoztatást, de éppen ennek következtében bizonyul bölcsnek, azaz ismeri fel, hogy miben is áll az emberi bölcsesség az isten szerint. ${ }^{44}$

Figyelemre méltó, hogy Oidipus jóslata szintén önbeteljesítő, csakhogy épp amiatt, hogy bölcsnek hiszi önmagát: azt hiszi, tudja, mi a jóslat értelme, hiszen tudni véli, ki ő - a korinthosi király és királyné fia. Ezért nem indul hazafelé, hanem Théba felé: menekül a jóslat beteljesítése elől, de éppen ezzel teljesíti be azt. Ez a hiba (hamartia) azt jelzi, hogy nem csupán szó szerinti értelemben, hanem delphoi értelemben sem „ismeri

${ }^{43}$ Az aporia oka tehát Sókratés esetében - az általa megvizsgáltakkal ellentétben - az, hogy nem hiszi magát bölcsnek (P1), azaz tudatában van (vélt) tudása bizonytalanságának. Nem lehet elégszer hangsúlyozni, hogy a sókratési „tudós tudatlanság” (docta ignorantia) nagy karriert befutott értelmezése, mely szerint Sókratés „tudja, hogy nem tud semmit”, téves. Sókratés egyetlen kortárs tudósításban - se Platónnál, se Xenophónnál - nem állítja ezt, tehát nem vitat el magától kategorikusan minden tudást. (Ráadásul a kijelentés evidensen öncáfoló, ilyesmit még Xenophón sem varr Sókratés nyakába, Platónról nem is beszélve.) A platóni Védőbeszédben három passzusra volna alapozható egy ilyen kijelentés, azonban Platón mindháromban körültekintően elveszi az élét a tudás kategorikus tagadásának. Az egyik így szól: „mert ugyan alighanem (kindyneuei) egyikünk sem tud semmi szépet és jót..." (21d3-4). Először is, itt csak a „szép és jó” dolgokra (a legfontosabb erkölcsi és politikai kérdésekre) vonatkozó tudásról van szó; másodszor az „alighanem” módosító szó a kijelentésnek valószínűséget, nem pedig bizonyosságot (= tudás) tulajdonít. A második így szól: „Csakhogy, alighanem (kindyneuei) úgy áll ez a dolog férfiak, hogy valójában egyedül az isten bölcs, és ezzel a jóslattal azt mondja, hogy az emberi bölcsesség igen keveset avagy semmit nem ér” (23a5-7). Itt ismét módosít az „alighanem” kifejezés, és ha a „bölcsességet” „mindentudásként” értjük (márpedig az istenre vonatkozóan úgy kell értenünk), akkor az értelme körülbelül ez: az ember meglehetősen messze, sőt tökéletesen távol áll az isteni mindentudástól. A közvetlenül ezután következő, harmadik passzusnak gyakorlatilag ugyanez az értelme: „Az közöttetek a legbölcsebb, aki Szókratészhez hasonlóan fölismerte, hogy bölcsesség tekintetében igazság szerint semmit sem ér" (23b2-4): az ember végtelenül távol áll a mindentudástól. A „tudom, hogy nem tudok semmit" kijelentés továbbá ellentmond a Védőbeszéd két olyan passzusának is, ahol Sókratés explicit módon vagy közvetve tudást tulajdonít magának (29b6-7, 41c9-d2). A Védőbeszédhez írt Utószóban a konstans (a jóslat megfejtését követô) sókratési vizsgálatra és önvizsgálatra alapozva további érveket hozok a docta ignorantia nagy karriert befutott, téves értelmezésével szemben: Mogyoródi E.: Utószó a Szókratész védőbeszédéhez és az Euthüphrónhoz. In: Platón: Euthüphrón, Szókratész védőbeszéde, Kritón. Ford. Mogyoródi E. (Euthüphrón, Szókratész védőbeszéde) és Gelenczey-Miháltz A. (Kritón). Budapest (2005) 132-133.

${ }^{44}$ Lásd még Mogyoródi: $i . m$. (43. j.) 129-130. 
önmagát", mivel - Sókratésszel ellentétben - nem vesz tudomást Delphoi intéséről, az emberi tudás határairól. Úgy van vele, mint akiket Sókratés megvizsgált: azt hiszi, tud valamit (ti. hogy mit jelent a jóslat), amit pedig nem tud. Ez a nem-tudás a végzete. Ám ez nem olyasmi, amit ne lehetne és kellene tudnia. Lehetne tudnia, hiszen senki és semmi nem akadályozza meg benne, ellenkezőleg, minden körülmény rendelkezésére áll, hogy ha magába szállna - miként Sókratés teszi $-{ }^{45}$ ha számot vetne önnön realitásával (sérült lába jelezte végességével), ne „ismerhetne önmagára”. És kellene is tudnia, hogy elkerülhesse a tragédiát.

Arra hívnám fel a figyelmet, hogy Oidipus nem-tudása éppen az a fajta „kettős tudatlanság", melytől Sókratés kívánja megszabadítani polgártársait a vizsgálódásaival. Platón $A$ szofista címủ dialógusában tesz világos különbséget a tudatlanság - s ennek megfelelően az okítás - két fajtája között: az egyik az egyszerủ ismerethiány (agnoia), melyet tanítással (didaskaliké) lehet orvosolni. A másikat azonban „súlyosabb fajta” tudatlanságnak nevezi az eleai vendég (a beszélgetés vezetője), és azt állítja róla, „alighanem mindnyájan ennek köszönhetjük minden tévedésünket, aminek gondolkodásunk ki van téve” (Pl. Sph. 229c5-6). ${ }^{46}$ Ez nem más, mint „amikor az ember nem tud valamit, mégis azt hiszi, hogy tudja” (229c5), mely „oktalanságnak” (amathia) nevezhetö, és nem tanítással, hanem neveléssel (paideia) orvosolható. Mint a későbbiekben kiderül, a Vendég azért tartja súlyosabb bajnak az oktalanságot, mert abban az emberben, ,aki valamiben bölcsnek hiszi magát, nem lesz hajlandóság valaha is olyasmit tanulni, amihez - úgy képzeli - kiválóan ért" (230a6-8) - vagyis saját tudására vonatkozó tévhite megakadályozza, hogy korrigálja helytelen nézeteit. Ez tehát annyiban nevezhető „kettős tudatlanságnak”, hogy az illető nem egyszerüen nem tud valamit, hanem azt sem tudja, hogy nem tudja. S mivel nem tudja, hogy nem tudja, hanem azt hiszi, hogy tudja, ezért nincs benne semmiféle hajlandóság, hogy az igazságot kiderítse vagy másoktól befogadja.

Mármost, ennek a bajnak az orvoslásához a nevelés egy speciális eljárására van szükség, mely nem más, mint a Sókratésre jellemző elenchtikus (cáfoló) módszer. ${ }^{47}$ A helytelen vélekedésektől ugyanis csak úgy lehet megszabadítani valakit, hogy egy kérdés-felelet formájában zajló beszélgetés során beszélgetőpartnere feltárja az illető téves nézetei között az ellentmondásokat, ezáltal megcáfolja és megszégyeníti őt, így eléri, "hogy egyedül arról higgye azt, hogy tudja, amit tényleg tud is, és semmi másról ne" (230b-d). Az elai vendég ezt a cáfolatot „a legfontosabb és leghatásosabb tisztító eljárásnak" (katharsis) (230d7-8) nevezi, mivel azt teszi a lélekkel, amit az orvosok a testtel, „akik úgy gondolják, hogy a test nem veheti hasznát a neki nyújtott tápláléknak, míg valaki el nem távolítja belőle mindazt, ami ebben megakadályozza..." Ugyanígy a lélek sem

45 Vö. 39. j.

${ }^{46}$ A szofista szövegét a továbbiakban is Bene László fordításában idézem. A kétfajta tudatlanságra vonatkozóan lásd még Pl. Hp.ma. 118b, Ap. 21d, Men. 84c, Smp. 204a; X. Ap. IV.2.

${ }^{47}$ Vö. Bene László kommentárját: Platón: A szofista. Kövendi Dénes fordítását átdolgozta, a jegyzeteket és az utószót írta: Bene László. Budapest (2006) 47, 49. j., 165-172. A sókratési módszerről bővebben lásd Steiger K.: Utószó. In: Platón: Nagyobbik Hippiasz, Kisebbik Hippiasz, Lakhész, Lüszisz. Budapest (2003) $172-192$. 
„veheti semmi hasznát a közölt ismereteknek”, míg valaki alá nem veti a cáfolatnak, „és meg nem szabadítja az ismeretek útjában álló vélekedéseitől” (230c-d).

A sókratési módszer nem más, mint a kritikai tudat eljárása, melyet ő - $\mathrm{s}$ vele együtt Platón - a filozófia lényegéhez tartozónak, de legalábbis propedeutikának tekint hozzá. Ezzel olyasmit proponál, amit a delphoi önismeret imperatívusza is, mely jóval régebbre visszanyúló görög belátás, mint gondolnánk. Hiszen már az Iliasból megtudjuk, hogy a „légy mindig első, mind közt kimagasló” (Hom. Il. VI. 208 = XI. 784) Achilleusnak adott felszólítása csupán az emberek közötti elsőséget jelenti, de azt határozottan nem, hogy bármely ember - legyen bár a legkiválóbb - istennek képzelje önmagát. ${ }^{48}$ A filozófia (a bölcsességre való törekvés vagy vágyakozás, szemben a bölcsesség birtoklásával, mely isteni prerogatíva ${ }^{49}$ ) ebben az értelemben minden ember előtt nyitva áll, aki képes leküzdeni a „kettős tudatlanság” életveszélyes önáltatását. ${ }^{50}$ A sókratési „tisztító eljárás” egy olyan katharsis, melynek célja a tragikus fordulat és felismerés, s a nyomukban keletkező katarzis megelözése. ${ }^{51}$

Mert nincs menekvés, az embernek - így vagy úgy - meg kell tisztulnia, mégpedig alapvetően a saját magára vonatkozó illúzióitól, hamis vélekedéseitől, önáltatásától, önelégültségétől. A tragikus hamartia tudatlanságból fakad, ${ }^{52} \mathrm{~s}$ ha abból fakad, akkor felelősséggel tartozunk érte. Mert lehetséges ugyan, hogy az oktalanság (amathia) „önkéntelen és akaratlan” (Sph. 230a6), de már ennek cáfolat utáni beismerése - normál kognitív képességeket feltételezve - nem az. ${ }^{53}$ Persze a platóni dialógusokban Sókratés egyetlen beszélgetőpartnere sem jut el idáig, ${ }^{54}$ még ha egyébként elvileg örömmel veszik

${ }^{48}$ Erről bővebben lásd Mogyoródi E.: Szabadság és erkölcsiség a homéroszi világban. Ókor VI/1-2 (2007) 5.

49 Vö. Pl. Ly. 218a-b, Phdr. 278c, Smp. 204a.

${ }^{50}$ Ehhez nem feltétlenül szükséges beszélgetőpartner, az elenchost egyedül is lehet végezni. Epiktétos valószínűleg nem téved nagyot, amikor ezt írja Sókratésről: „Mivel nem lehetett mellette mindig egy olyan beszélgetőtárs, aki szembeszállhatott volna a nézeteivel (elenchonta), vagy akinek a meggyőződéseit a legapróbb részletekig próbára tehette volna (elenchthésomenon), ezért önmagát vonta kérdőre (élenchen), és saját nézeteit vizsgálta meg, és mindig valamely alapfogalom gyakorlásával foglalkozott” (Epict. Gnom. II.1.32. Steiger Kornél fordítása). Lásd még Mogyoródi: $i$. m. (33. j.) 32.

51 Vö. 4. j. Xenophónnál Sókratés azt állítja, hogy ha valaki nem ismeri önmagát, és olyasmiről hiszi, hogy tudja, amit nem tud, az az őrültséggel (mania) határos állapotban van (Mem. III. 9. 6). Éppen ezt illusztrálja a sophoklési Oidipus alakja.

${ }_{52}$ Aristotelés meghatározása szerint a felismerés a tudatlanságból (agnoia) a tudásba (gnósis) való átváltás (Po. XI. 1452a30-31). Erről lásd P. Boitani: Anagnorisis: Scenes and Themes of Recognition and Revelation in Western Literature. Leiden - Boston (2021) 13-16. A felismerés személyekre (rokonokra, barátokra vagy ellenségre) vonatkozik, azonban Oidipus esetében ez éppenséggel saját maga, a saját valódi kiléte. Vö. Vernant: i.m. (4. j.) 117-118.

${ }^{53}$ Ezért az „oktalanságot” helyesebb volna „okulni nem akarásként” értelmezni. Vö. Mogyoródi: $i$. $m$. (33. j.) 26 .

54 A szofistában az eleai vendég meglehetősen naivan (a passzust csak ironikusan tudom érteni) azt feltételezi, hogy „az illető pedig ezt [ti. a saját nézetei között kimutatott belső ellentmondásokat] látva elégedetlen lesz önmagával, másokkal viszont türelmesebb, s ily módon megszabadul az önmagáról táplált nagyzoló és merev véleményétől - ez a szabadulás annak is igen kellemes, aki hallja, aki pedig átéli, a legszilárdabb alap a jövőre" (230b-c). Ez a hozzáállás a platóni dialógusokban csupán Sókratésre jellemző (vö. pl. Grg. 486d, 506a). 
is (ami szintén ritkaság), hogy Sókratés nekilát, hogy megvizsgálja öket. ${ }^{55}$ Ehelyett a legtöbben a nyilvánvaló cáfolat után durcás hallgatásba merülnek, cinikusan gúnyolódnak, elmenekülnek vagy egyenesen agresszívek lesznek Sókratésszel szemben - vagyis ellenállnak a katartikus eljárásnak, mert túlságosan fájdalmas szembenézni valódi önmagukkal, gondolkodásuk zavaros voltával, tudásuk korlátoltságával. Sophoklés - ugyanerre az örök emberi tényezőre reflektálva - Oidipus történetével arra int, hogy ennek csak tragédia lehet a vége. ${ }^{56}$

Nem arról van szó, hogy Oidipus erkölcstelen bűnös, aki elnyeri megérdemelt büntetését, míg Sókratés valamiféle filozófiai szent, aki racionalitásával és moralizálásával valójában elnyomja vagy tagadja, nem pedig meghaladja a condition humaine véres valóságát. ${ }^{57}$ De nem is arról, hogy a tragédia arra tanít, hogy a bün elkerülhetetlen. ${ }^{58}$ Oidipus és Sókratés története arra figyelmeztet, hogy nem a bűn, hanem a szenvedés az, ami az emberi életben elkerülhetetlen - az önismerethez, a megbékéléshez, a hazatéréshez, a megváltáshoz. ${ }^{59}$ Sókratés elkerülte a bűnt vagy vétket - így a sors nem is szakadt rá -, de nem kerülte el, sőt, egyenesen felvállalta a szenvedést, $\mathrm{s}$ a szenvedésen keresztüli megtisztulást. ${ }^{60}$ Csak egy választásunk van: a kétféle, a tragikus és a filozófiai katarzis közötti. S ez egyedül rajtunk áll.

${ }^{55}$ Ilyen kivétel a szókratikus dialógusokban Nikias és Lachés a Lachésban (La. 187e-188c, 189a-b), ám az effektív cáfolatot azért már ők sem fogadják kitörő örömmel (194a-b, 196a-b, 200a-c).

56 Innen tekintve nem tudok egyetérteni Heller Ágnes utolsó könyvében kifejtett koncepciójával (legalábbis, ami a görögséget illeti), mely szerint a filozófia felváltja vagy lerombolja a tragédiát, illetve az erkölcsfilozófia az előbbiből fejlődik ki: Heller: $i$. m. (26. j.) 5-6, 27, 33, 54-57, 60, 62-64, 294. A tragédia és a filozófia (legalábbis a sophoklési tragédia és a sókratési-platóni filozófia) hasonló választ ad legalábbis egy bizonyos, örök emberi kérdésre, a delphoi értelemben vett önismeret problémájára vonatkozóan.

${ }^{57} \mathrm{Ez}$ Nietzsche híres koncepciójának lényege Sókratés anti-tragikus „optimizmusára” vonatkozóan. Lásd F. Nietzsche: A tragédia születése avagy görögség és pesszimizmus. Ford. Kertész Imre. Budapest (1986) 99-128. Ez a koncepció máig széles körben hatást gyakorol a tragédia és a filozófia kapcsolatáról gondolkodókra. Vö. Heller: i. m. (26. j.) 32-34, 54, 62-63, 293-294; Dethlefsen: i. m. (15. j.) 62. Ahrensdorf azonban egy egész könyvet szentelt annak, hogy Nietzschével - és az őt követő modern koncepciókkal - szemben kimutassa, a sophoklési tragédia sokkal közelebb áll a filozófiai világképhez, Sókratés és Platón pedig nem érzéketlen az emberi élet tragikus dimenzióival szemben: P. J. Ahrensdorf: Greek Tragedy and Political Philosophy: Rationalism and Religion in Sophocles' Theban Plays. Cambridge (2009).

58 Dethlefsen: $i$. m. (15. j.) 47, 56-57.

59 Az Oidipus Kolónosban, mely Oidipus száműzetésben történő hányattatásainak ábrázolása után Oidipus csodaszerű apoteózisával ér véget, értelmezésemben ezt üzeni.

${ }^{60}$ Itt az elenchos katartikus eljárására is gondolok, melynek Sókratés maga készségesen vetette alá saját magát (vö. 50. és 54. j. és Pl. Ap. 28e), a küldetésére is, mely fáradalmakat és kockázatot jelentett számára (Pl. Ap. 22a, 28a, 28d-29a, 30a-b, 31b-c, 34c, 36b-e, 38e), s végül a „szép halál” felvállalására is (Pl. Ap. Cri. Phd.). 


\title{
SUMMARY
}

This paper is a comparative study on the iconic Greek heroes, Oedipus and Socrates. In particular, it contrasts their responses to the Delphic oracle and argues that Oedipus' hamartia, his hubris consists in "double ignorance", a state of which the Socratic elenchos is meant to purge citizens of Athens. In contrast with Oedipus, Socrates evades tragedy, for he takes the Delphic admonition ("Know thyself!") to heart. Socratic philosophy is a cathartic procedure meant to preclude tragic catharsis. Sophoclean tragedy and the SocraticPlatonic philosophy respond to the same, perennial human hubris of "double ignorance", and their lesson is similar. Wavering between appearance and reality, opinion and knowledge - as $5^{\text {th }}$ century Greeks were - our choice is the same today: that between tragic and philosophical catharsis.

Keywords: Oedipus, Socrates, Delphic oracle, hamartia, hubris, appearance, reality, double ignorance, elenchus, catharsis, tragedy and philosophy

\author{
MOGYORÓDI EMESE \\ Szegedi Tudományegyetem \\ Filozófia Tanszék \\ mse@philo.u-szeged.hu
}

Open Access. A cikk a Creative Commons Attribution 4.0 International License (https:// creativecommons.org/licenses/by/4.0) feltételei szerint publikált Open Access közlemény, melynek szellemében a cikk bármilyen médiumban szabadon felhasználható, megosztható és újraközölhető, feltéve, hogy az eredeti szerző és a közlés helye, illetve a CC License linkje és az esetlegesen végrehajtott módosítások feltüntetésre kerülnek. (SID_1) 